\title{
When can physical distancing be relaxed? A health production function approach for COVID-19 control policy
}

Dradjad H. Wibowo ( $\sim$ dhwibowo@indef.or.id)

INDEF / Perbanas Institute https://orcid.org/0000-0002-4665-2691

\section{Research Article}

Keywords: COVID-19, physical distancing, pandemic control policy, state of transmission, health production function, production elasticity, developing countries.

Posted Date: October 6th, 2020

DOI: https://doi.org/10.21203/rs.3.rs-87332/v1

License: (c) (i) This work is licensed under a Creative Commons Attribution 4.0 International License. Read Full License

Version of Record: A version of this preprint was published at BMC Public Health on June $2 n d, 2021$. See the published version at https://doi.org/10.1186/s12889-021-11088-x. 
When can physical distancing be relaxed?

\section{A health production function approach for COVID-19 control policy}

Dradjad H. Wibowo

4

5

Abstract

6

\section{Background}

Physical distancing measures to control the COVID-19 pandemic come at a heavy short-term economic cost. But easing the measures too early carries a high risk of transmission re-escalations. To assess if physical distancing can be relaxed, a number of epidemic indicators are used, most notably the reproduction number R. Many developing countries, however, have limited capacities to estimate R accurately. This study aims to demonstrate how health production function can be used to assess the state of COVID-19 transmission and to determine a risk-based physical distancing relaxation policy.

\section{Methods}

The author establishes a short-run health production function, representing the cumulative number of COVID-19 cases, from the standard SIR model. Three zones defining the state of transmission are shown. The probability of meeting a policy target, given a production elasticity range, is computed.

21 The method is applied to France, Germany, Italy, the UK and the US, and to Indonesia as an example of application in developing countries.

\section{Results}

26 As of June 30, 2020, France, Germany, Italy and the UK have arrived in the "green zone" where relaxation can be considered. The US is still in the "red zone" where physical distancing still needs to be applied. France, Germany and Italy can set a policy target of maximum daily-cases of 500, while the UK has to make do with a target of 1,100 daily-cases. France, Germany, Italy and the UK still exhibit a relatively high risk of their daily-cases failing to meet the policy target or even rising. Indonesia is still 
31 in the "red zone", so it comes as no surprise that the country's daily-cases rose sharply after relaxation 32 of physical distancing.

\section{Conclusions}

Short-run health production function can be used to assess the state of COVID-19 transmission and to determine a risk-based physical distancing relaxation policy. Given its simplicity and minimum data requirement, the approach is very useful for developing countries which are unable to have reliable estimates of the reproduction number $R$. Follow-up research from this study may include estimating an economically optimal date for relaxing distancing measures and application of this method to other epidemics.

\section{Keywords:}

COVID-19, physical distancing, pandemic control policy, state of transmission, health production function, production elasticity, developing countries.

\section{Introduction}

To control the rapid spread of the coronavirus disease 2019 (COVID-19) pandemic, many countries employ community-wide physical (social) distancing measures. These measures usually include border closing, movement restriction, school, workplace, and public-place closures, prohibition of gatherings, isolation and or quarantine. These measures constitute a pandemic control policy termed "large-scale public health restrictions" by the World Health Organization (WHO) [1].

The short-term economic costs of physical distancing, however, can be very high. At the macro level, a 6-weeks social distancing is estimated to lower the Gross Domestic Product (GDP) of 15 European countries by 4.3-9.2\% [2]. Using an Effective Lockdown Index (ELI), a 14\% contraction of the global

58 GDP on a year-on-year basis has also been estimated [3]. At the micro level, physical distancing adversely affects household income. It is estimated that the US' household income could decline by 
62 At the global level, in June 2020 the International Monetary Fund (IMF) estimates that the COVID-19 63 pandemic and its containment policies could subdue the 2020 global economic growth to $-4.9 \%$, an $648.2 \%$ correction from its January 2020 projection [5]. In its June 2020 Economic Outlook, the 65 Organisation for Economic Co-operation and Development (OECD) projects a 6\% contraction of the world's economy in a single-hit scenario, and a $7.6 \%$ fall if there is a second wave of infections before the end of 2020 [6]. This contraction will cause higher global unemployment.

Notwithstanding the short-term economic costs, in the long-term the economic benefits of social distancing have been shown to outweigh the costs. Over a 30 -year planning horizon using a $3 \%$ discount rate, effective social distancing produces economic net benefits of about US\$ 5.2 trillion [7]. Evidence from the 1918 Flu Pandemic in the US also shows the economic benefits of social distancing as a non-pharmaceutical intervention (NPI). Cities that intervened earlier and more aggressively with an NPI had an increased economy after the pandemic [8].

If social distancing is not applied, the economic costs can be much higher. A two-sector analysis of the US Input-Output Table shows that without social distancing, the falls in output, capacity utilization and investment is around two-folds of those with social distancing [9]. If social distancing goes wrong, the economy could experience another severe hit [9]. If social distancing is "just slightly too relaxed", the net economic result would be worse than doing nothing [10].

Once distancing measures are applied, given their high economic costs, the policy challenge facing governments is to determine when the measures can be relaxed without increasing the risk of transmission re-escalations. In this case, WHO recommends that COVID-19 transmission should come under control [1], based on a number of epidemic indicators, most notably the reproduction number $R$. Developed countries such as Germany use $R$ as a benchmark to ease lockdown; its $R$ prior to the easing was 0.8 [11]. The UK frequently releases its $R$ and growth rate figures, which as of June 25,2020 were $0.7-0.9$ and $-4 \%$ to $-2 \%$, respectively [12]. The UK government did not, however, solely rely on these indicators to ease lockdown measures. 
91 For developing countries, estimating R can be very problematic. Many developing countries have very 92 limited financial and research capacities to estimate $\mathrm{R}$ accurately on a daily basis. They have a 93 relatively inferior health data collection system, making them unable to accurately estimate the basic 94 reproduction number $\mathrm{R}_{0}$ in the early stages of a pandemic. Fiscal tightness limits their ability to 95 conduct large-scale test and tracing programs. With only a tiny fraction of the population is tested, the 96 accuracy of any estimate of $\mathrm{R}$ is highly questionable.

In this study, the author proposes the use of short-run health production function as an additional approach to assessing the state of COVID-19 transmission. The author shows that with a minor adjustment, the cumulative number of COVID-19 cases can be constructed as a short-run total product

101 function. One can then use the function to estimate the corresponding marginal and average products, the production elasticity and the relevant Bayesian probabilities to determine a risk-based pandemic control policy. This approach is very simple and straightforward, which can be performed easily by developing countries officials.

105

\section{Methods}

108 Since Grossman's seminal work [13], there have been a large body of research on health production

109 function. These research use community or individual health status as the output variable, measured for

110 example by morbidity [14], mortality or individual health status, with inputs such as health care, safe 111 water and sanitation, habits (e.g. diet, smoking) and other relevant variables.

112

113 This study employs time as the health input variable. Because only one variable is used, we are dealing

114 with a short-run health production function. The cumulative number of COVID-19 cases is employed 115 as the health status output.

116

117 Now consider the Susceptible-Infected-Recovered (SIR) model, with $S(t), I(t), R(t)$, and $t$ representing

118 the susceptible, the infected, the recovered, and time, respectively. Defining $Y(t)$ as a twice119 differentiable function given by the integral of $I(t)$ with respect to (w.r.t) time from $t=0$ to $t=\tau$, it 
follows that for $\forall \tau>0, Y(\tau)$ is the cumulative number of the infected or the cumulative number of

121 cases from $t=0$ to $\mathrm{t}=\tau$. Thus, we have $Y(t)$ as a short-run health production function.

122

123

124

125

126

127

128

129

130

131

132

133

134

135

136

137

138

139

140

\section{1}

142

143

144

145

146

147

The main departure of $Y(t)$ from the standard short-run production function in economics is that it has no downward curve. This is because the cumulative number of cases does not decrease unless there is a change in the definition of cases or an incorrect recording of data. The corresponding marginal product of the infected $(M Y)$, the average product of the infected $(A Y)$, and the production elasticity of the infected w.r.t time $t(\varepsilon t)$ can then be derived from $Y(t)$. Note that $\varepsilon t$ is defined as the percentage change in $Y(t)$ for every one per cent change in $t$. This procedure is formally presented in Additional file 1.

Because the number of confirmed COVID-19 cases is reported daily, and recognizing that these data are the best available guesses of the true number of the infected, we can let $d t=$ one reporting day. Thus, without any need to estimate the functional form of $Y(t)$, we can compute $M Y, A Y$, and $\varepsilon t$ directly from these data. Because $M Y=I(t)$, that is the number of daily COVID-19 cases at time $t, M Y$ and $I(t)$ are used interchangeably. Note that $M Y=I(t) \geq 0$. For reason of definition rigor [15], this study uses arc elasticity, even though estimates of both arc- and point-elasticity are presented

Because $Y(t)$ and $I(t)$ are time-series variables, to have clearer trends the author smooths out the data using 5-day exponential moving average (EMA), assuming an incubation period of 5 days as used by Kucharski et al [16]. The author uses 5-day EMAs as the bases of analysis.

\section{Pandemic control inferences from $Y(t), M Y, A Y$, and $\varepsilon t$}

Figure 1 illustrates the pandemic control inferences that can be drawn from $Y(t), M Y, A Y$, and $\varepsilon t$ for $I(t)$ $\geq 0$. The curves shown are the standard short-run total, marginal and average products where the marginal product is equal or greater than zero. The inferences depend on whether three crucial periods determining the state of transmission, i.e. $t_{1}, t_{2}$, or $t_{3}$, have been reached. They are described as follows: 
1. Before $t_{l}$ is reached, $M Y=I(t)$ has not peaked and is still rising, and $\varepsilon t>1$. Policy makers need to apply physical distancing measures to stop the rise, and to bring the number of daily cases down. This state is represented by the "red zone" in Figure 1.

2. At $t_{l}, M Y$ reaches its peak, which corresponds to the inflection point $Y_{l}$. From $t_{l}$ to $t_{2}, I(t)$ declines. Naturally, policy makers start to think if distancing measures can be relaxed. But at this state of transmission, $M Y>A Y$ and $\varepsilon t>1$. Relaxing the measures is not recommended. This state is represented by the "yellow zone" in Figure 1.

3. At $t_{2}, A Y$ reaches its peak and $\varepsilon t=1$. From $t_{2}$ to $t_{3}$, both $M Y$ and $A Y$ decline, $M Y \leq A Y$, and $0 \leq$ $\varepsilon t \leq 1$. Relaxation of distancing measures can be considered at this state of transmission, depicted by the "green zone" in Figure 1.

4. At $t_{3}, M Y=I(t)=0$. No more daily COVID-19 cases are recorded; $Y(t)$ reaches its steady-state.

160 At a given time $t$, the question is then "is now the right time to relax the measures?" To answer this and 161 to showcase inferences \#2 and \#3, the author assumes that policy makers rationally adopt risk-based 162 decision-making. They need to assess the probability of near term's daily COVID-19 cases being equal 163 to or below a given daily-cases target of $I^{*}$. This probability is conditional on $E$ t because the condition

$164 \varepsilon t \leq 1$ must be satisfied. $I^{*}$ may be set in accordance to the number of daily-cases that a health system 165 can handle, or be determined arbitrarily based on, say, a socio-political process. A rational policy 166 maker will only relax distancing measures if the probability is high. A more cautious one might add 167 another target such as "constant or declining number of daily-cases".

\section{Results}

171 To test this approach, the author initially analyses COVID-19 cases in France, Germany, Italy, the UK 172 and the US. The analysis only needs data on the cumulative (or the daily) number of COVID-19 cases 173 and their recording dates, which for these countries are obtained from Coronavirus Statistiques [17].

174 The method is then applied to Indonesia's COVID-19 data [18] as a developing country example, given 175 the author's familiarity with its health data collection system. The data covers a period from the first 176 day a confirmed case is recorded until June 30, 2020. 
180 Descriptive statistics of the data are given in Table 1. Figure 2 presents the 5-day EMA curves of $Y(t)$, $181 M Y=I(t)$, and $A Y$. See Additional file 2 for the corresponding curves from original data.

182

184 arrived at the steady-state of $Y(t)$. the latest one..

From France's, Germany's, Italy's and the UK's curves in Figure 2, it is obvious that $Y(t), M Y$, and $A Y$ have the curvature of short-run total, marginal, and average products, respectively. With regard to the state of transmission, these countries have all reached $t_{l}$ with Italy being the earliest one and the UK

The US on the contrary has not reached $t_{l}$. It appeared to reach $t_{l}$ on April 25, but the EMA data show new heights of $I(t)$ on June 26-27. As this study covers data until June 30, 2020, the author has no adequate data to consider June $26-27$ as the US' $t_{1}$. On May 21 the US reported a sharp drop in $I(t)$, making its $M Y$ falling below its $A Y$. But because its $A Y$ is still rising and the sharp fall is not sustained on the days after, the fall is considered a statistical outlier. All these explain why currently $Y(t)$ in the US has yet to exhibit the standard total product curve.

With regard to $t_{2}$, Germany reached it on April 20. France and Italy reached it a few days later, while the UK almost a month later. On May 6 France recorded a large jump in its daily cases, resulting in $M Y>A Y$. But France's $A Y$ has been declining from April 22-24, and its $M Y$ is lower than its $A Y$ from May 7 to June 30. So the May 6 jump is seen as an outlier.

\section{(Table 1 and Figure 2 can be placed here)}


210 Table 2 presents the arc production elasticity $(\varepsilon t)$ for these countries. Point elasticity values are also

211 presented for comparative purpose. In general, arc elasticities are larger than point elasticities for all 212 countries. Italy has the smallest $\varepsilon t$, with a mean of 1.45 . This means that for every one per cent change 213 in time, Italy has 1.45 per cent additional COVID-19 cases. The US exhibits the largest $\varepsilon t$ with a 214 maximum value of 9.07.

(Table 2 can be placed here)

218 The UK's $\varepsilon t$ has a mean of 2.20, larger than France's, Germany's and Italy's. With a much lower 219 coefficient of variation (CV), the UK's $\varepsilon t$ is much less dispersed around its mean value. These results reflect the UK's persistently higher daily COVID-19 cases, and its inferior ability to suppress both $I(t)$ and $E t$ compared to France, Germany and Italy.

\section{Probability of a policy target}

The next analysis is not relevant for the US because it has yet to reach $t_{1}$. Now let's assume that based on the latest $I(t)$ records, France, Germany and Italy set the policy target $I^{*}$ arbitrarily at 500 daily-

231 For $E t>1$ (the "yellow zone"), the probability of $I(t+1) \leq 500$ is zero for these countries. This means, even though France, Germany, and Italy have reached $t_{l}$, they have a zero chance of supressing their 233 near term's daily-cases below or equal to 500 . After reaching $t_{t}$, with $\mathcal{E} t>1$ they only have a probability 234 of greater than zero if $I^{*}$ is set higher than 500. For example, France will have a probability of 0.04 if $235 I^{*}$ is set at $1,507.1$. This explains why relaxation is not recommended in this transmission state. 
237 If a country reaches $t_{2}$, they have $0 \leq \varepsilon t \leq 1$. As shown in Table 3 , the probabilities of $I(t+1) \leq 500$ are $2380.47,0.37$, and 0.50 for France, Germany and Italy, respectively. If policy makers aim at having a 239 larger probability, they need to set a lower elasticity range. Table 3 presents the probabilities if the 240 range is set at $0 \leq \varepsilon t \leq 0.5$ and $0 \leq \varepsilon t \leq 0.2$. For $0 \leq \varepsilon t \leq 0.2$, France has a probability of 0.71 (five out 241 of seven cases), Germany 1.00 (nine out of nine cases) and Italy 1.00 (30 out of 30 cases).

243 If $I(t+1) \leq I(t)$ is put as an additional target, the probabilities return lower values, except for $\varepsilon t>1$ where 244 the probabilities are again zero. For $0 \leq \varepsilon t \leq 0.2$, Germany and Italy have a probability of 0.33 (three 245 out of nine cases) and 0.67 (20 out of 30 cases), respectively. Against expectation, France's probability 246 of 0.29 (two out of seven cases) is lower than its probability in the $0 \leq \varepsilon t \leq 0.5$ range. France's erratic 247 data on May 6, May 28, May 30, June 2 and June 24-25 cause this irregularity, and an EMA longer 248 than 5 days is needed to smooth out the data.

250 The UK shows similar results but with a much higher $I^{*}$ of 1,100 . This is because for $I^{*}<1,100$ the UK 251 has no or only few records that meet the threshold. For example, the UK has no records that meet $252 I^{*}=500$ because currently this level is unattainable. For $I^{*}=1,100$ the UK has seven data records, 253 returning a probability of 0.41 at $0 \leq \varepsilon t \leq 0.5$ and 0.75 at $0 \leq \varepsilon t \leq 0.4$. If the $0 \leq \varepsilon t \leq 0.2$ range is 254 used, the probability becomes zero because the UK's lowest elasticity is 0.34 . For the $I(t+1) \leq I^{*}$ and $I(t+1) \leq I(t)$ policy target, at $0 \leq \varepsilon t \leq 0.4$ the UK's probability is 0.50 (two out of four cases).

\section{Application to a developing country: Indonesia}

In January and February 2020 Indonesia denied that the country has a COVID-19 case. When the

260 central government finally announced the "first" COVID-19 case on March 2, opportunity to estimate $261 R_{0}$ more accurately has been wasted. Consequently, Indonesia has no reliable estimates of $R$ to assess 262 its state of transmission.

264 On the other hand, the results from France, Germany, Italy and the UK show that short-run health 265 production function and elasticity can be used to assess the state of transmission. As shown by Table 1 266 and Figure 2, Indonesia has not reached $t_{l}$. It means, the country is still in a transmission state where 
267 physical distancing needs to be applied to bring down the number of daily-cases. Yet on June 1

268 Indonesia began to relax physical distancing in some of its provinces in order to "save" the economy.

269 Unsurprisingly, Indonesia's daily-cases rose to a new height of 2,657 on July 9.

\section{Discussion}

273 This study demonstrates how short-run health production function is employed to assess the state of

274 COVID-19 transmission, using only data on the cumulative number of cases and the recording dates.

275 The data are processed in a relatively simple way in Microsoft Excel. To view how the calculations are

276 done, see Additional files 3-8. This simple approach can be performed at minimal costs in developing

277 countries. Needless to say that the accuracy of the results depends data quality.

279 This study also show that relaxing physical distancing measures can only be considered when the state

280 of transmission is in the "green zone". In this zone the probability of maintaining a relatively low 281 number of near term's daily COVID-19 cases, at a given elasticity range, is relatively high. In the 282 "yellow zone" the probability is zero or near zero.

284 As of June 30, 2020, France, Germany, Italy, and the UK have all arrived at the "green zone". With a 285 policy target of 500 daily-cases, France, Germany, and Italy need to have a very low elasticity of 0.2 to 286 return a probability larger than 0.7 . At a higher elasticity, their probability can fall below 0.5 . If the 287 policy target includes "keeping a constant or declining number of daily-cases", their probabilities are 288 below 0.5, except for Italy. In other words, France and Germany still have a high risk of their daily289 cases rising.

291 The UK must make do at a higher target of 1,100 daily-cases, and yet, the probability of meeting the 292 target is relatively lower. The UK also has a higher risk of its daily-cases rising. The US and Indonesia 293 are still in the "red zone", hence, physical distancing measures need to be applied in these countries. 


\section{Conclusions}

299 Short-run health production function can be used as an additional method to assess the state of

300 transmission and to determine a risk-based physical distancing relaxation policy. Given its simplicity

301 and minimum data requirement, the approach can be very useful for developing countries which -- for

302 various reasons -- are unable, or miss the opportunity, to estimate $R_{0}$ thoroughly and accurately.

303 Indonesia is used as an example, and the results explain why the country's daily-cases rose sharply

304 after relaxation of physical distancing.

305

306 Follow-up research from this study may include estimating the functional forms of the short-run 307 production curves, examining elasticity conception that best explains an epidemic, estimating an 308 economically optimal date for relaxing distancing measures, the cost-benefit analysis of relaxation at 309 different states of transmission, and application of this method to other epidemics.

\section{Abbreviations}

313 COVID-19: Coronavirus disease 2019; WHO: World Health Organization; GDP: Gross Domestic 314 Product; ELI: Effective lockdown index; IMF: International Monetary Fund; OECD: Organisation for 315 Economic Co-operation and Development; NPI: Non-pharmaceutical intervention; SIR: Susceptible316 Infected-Recovered; EMA: Exponential moving average; CV: Coefficient of variation.

\section{Declarations}

\section{Ethics approval and consent to participate}

$321 \quad$ Not applicable

\section{Consent for publication}

325 Not applicable 
329 All data generated or analysed during this study are included in this published article and its 330 supplementary information files.

\section{Competing interests}

334 The author has no competing interests.

\section{$336 \quad$ Funding}

This study is self-funded by the author.

\section{Author's contributions}

The author designed, wrote and approved the study by himself.

344 Acknowledgment

346 The author thanks M. Ridzki Wibowo, Idznika N. Wibowo and Sarwo Edi for their assistance in data

347 collection and presentation of tables

\section{Author's information}

351 DHW is an Associate Professor in Economics at the Graduate School, the Perbanas Institute, Indonesia

352 and is a Senior Economist at the Institute for Development of Economics and Finance (INDEF), 353 Indonesia. 


\section{References}

359 1. WHO. Strengthening and adjusting public health measures throughout the COVID-19 transition 360 phases. Policy considerations for the WHO European Region. WHO Regional Office for Europe, 361 Copenhagen, 2020. https://www.euro.who.int/en/health-topics/health-emergencies/coronavirus362 covid-19/technical-guidance/2020/strengthening-and-adjusting-public-health-measures-throughout363 the-covid-19-transition-phases.-policy-considerations-for-the-who-european-region,-24-april-2020 $364 \quad$ [accessed 7 June 2020].

365 2. Barrot J, Grassi B, Sauvagnat J. Sectoral effects of social distancing. Published online April 15, 366 2020. http://dx.doi.org/10.2139/ssrn.3569446 [accessed 6 June 2020].

367 3. Hatzius J, Tilton A, Struyven D. Global economics analyst measuring the impact of lockdowns and 368 social distancing on global GDP. Published online April 26, 2020.

369 https://www.gspublishing.com/content/research/en/reports/2020/04/27/3a0089c7-c1d1-4243-8dbd370 da6141a501be.html [accessed 6 June 2020].

371 4. Strong A, Welburn JW. An estimation of the economic costs of social-distancing policies. June 372 2020. Santa Monica, California. RAND Corporation.

373 https://www.rand.org/content/dam/rand/pubs/research_reports/RRA100/RRA173-

374 1/RAND RRA173-1.pdf [accessed 6 June 2020].

375 5. IMF. World Economic Outlook Reports-World Economic Outlook Update, June 2020: A crisis like 376 no other, an uncertain recovery. IMF, Washington, June 2020.

377 https://www.imf.org/en/Publications/WEO/Issues/2020/06/24/WEOUpdateJune2020 [accessed 26 378 June 2020].

379 6. OECD. OECD Economic Outlook, June 2020: The world economy on a tightrope. OECD, Paris, 380 June 2020. http://www.oecd.org/economic-outlook/june-2020/ [accessed 12 June 2020].

381 7. Thunström L, Newbold SC, Finnoff D, Ashworth M, Shogren JF. The benefits and costs of using 382 social distancing to flatten the curve for COVID-19. Forthcoming J Benefit Cost Anal 2020; 383 published online April 14, 2020. http://dx.doi.org/10.2139/ssrn.3561934 [accessed 6 June 2020].

384 8. Correia S, Luck S, Verner E. Pandemics depress the economy, public health interventions do not: 385 evidence from the 1918 Flu. Published online March 30, 2020. 386 http://dx.doi.org/10.2139/ssrn.3561560 [accessed 6 June 2020]. 
387 9. Bodenstein M, Corsetti G, Guerrieri L. Social distancing and supply disruptions in a pandemic. 388 May 2, 2020. Cambridge-INET Working Paper Series No: 2020/17 Cambridge Working Papers in 389 Economics: 2031. https://www.inet.econ.cam.ac.uk/working-paper-pdfs/wp2017.pdf [accessed 6 390 June 2020].

391 10. Maharaj S, Kleczkowski A. Controlling epidemic spread by social distancing: Do it well or not at all. BMC Public Health. 2012; 12(1):1-16. https://doi.org/10.1186/1471-2458-12-679 [accessed 6 June 2020].

394 11. The Editorial Board of Wall Street Journal. Germany's R0 coronavirus experiment. WSJ Opinion. 395 April 28, 2020. https://www.wsj.com/articles/germanys-r0-coronavirus-experiment-11588115565 [accessed 2020 Jun 6].

397 12. The Government of the UK. Guidance: The R number and growth rate in the UK. Last updated 398 June 25, 2020. https://www.gov.uk/guidance/the-r-number-in-the-uk [accessed 3 July 2020].

399 13. Grossman, M. On the concept of health capital and the demand for health. J Polit Econ. 1972; 400 80(2): 223-225. https://www.journals.uchicago.edu/doi/pdfplus/10.1086/259880 [accessed 2 July $4012020]$.

402 14. Wibowo D, Tisdell C. Health, safe water and sanitation: a cross-sectional health production 403 function for Central Java, Indonesia. Bull World Health Organ. 1993; 71(2): 237-245. $404 \quad$ https://apps.who.int/iris/bitstream/handle/10665/47810/bulletin_1993_71\%282\%29_237405245. pdf? sequence=1\&isAllowed=y [accessed 2 July 2020].

406 15. Shishkin D, Olifer, A. Point elasticity versus arc elasticity: On different approaches to teaching 407 elasticity in principles courses. J of Economics and Economic Education Research. 2017; 18(2):1-7. 408 https://www.abacademies.org/articles/Point-Elasticity-Versus-Arc-Elasticity-1533-3604-18-2$409 \quad$ 111.pdf [accessed 18 June 2020].

410 16. Kucharski AJ, Russel TW, Diamond C, et al. Early dynamics of transmission and control of 411 COVID-19: a mathematical modelling study. Lancet Infect Dis. 2020; 20(5):553-558. 412 https://www.thelancet.com/article/S1473-3099(20)30144-4/fulltext [accessed 3 June 2020].

413 17. Coronavirus Statistiques. COVID-19 cases in Europe | live update. https://www.coronavirus414 statistiques.com/stats-globale/covid-19-cases-europe/ [accessed 1 June 2020]. 
415 18. Gugus Tugas Percepatan Penanganan COVID-19 (The COVID-19 Task Force). Situasi COVID-19

416 di Indonesia (COVID-19 Situation in Indonesia). https://covid19.go.id/peta-sebaran [accessed 1 417 June 2020].

418 
Tables and figures

Table 1. Descriptive statistics

\begin{tabular}{|c|c|c|c|c|c|c|}
\hline & France & Germany & Italy & The UK & The US & Indonesia \\
\hline Recording dates & $\begin{array}{l}\text { Feb 21- } \\
\text { June } 30\end{array}$ & $\begin{array}{l}\text { Feb 24- } \\
\text { June } 30\end{array}$ & $\begin{array}{l}\text { Feb 19- } \\
\text { June } 30\end{array}$ & $\begin{array}{l}\text { Feb 27- } \\
\text { June } 30\end{array}$ & $\begin{array}{l}\text { Feb 24- } \\
\text { June } 30\end{array}$ & $\begin{array}{l}\text { March 2- } \\
\text { June } 30\end{array}$ \\
\hline $\begin{array}{l}\text { Number of } \\
\text { recording days (t) }\end{array}$ & 131 & 128 & 133 & 125 & 128 & 121 \\
\hline \multicolumn{7}{|l|}{$\begin{array}{l}\text { Cumulative } \\
\text { number of cases, } \\
\text { Y(t), on June } 30 \text {, } \\
2020\end{array}$} \\
\hline Orignal data & 164,801 & 194,259 & 240,578 & 312,654 & $2,634,432$ & 56,385 \\
\hline EMA & 163,789 & 193,382 & 240,227 & 310,946 & $2,551,686$ & 53,961 \\
\hline \multicolumn{7}{|l|}{$\begin{array}{l}\text { Number of daily- } \\
\text { cases, My=I(t), } \\
\text { 5-day EMA }\end{array}$} \\
\hline Mean & 1,290 & 1,559 & 1,862 & 2,570 & 20,578 & 461 \\
\hline $\begin{array}{l}\text { Standard } \\
\text { deviation }\end{array}$ & 1288 & 1,637 & 1,762 & 1,810 & 11,182 & 358 \\
\hline $\begin{array}{l}\text { Coefficient of } \\
\text { variation }\end{array}$ & $100 \%$ & $105 \%$ & $95 \%$ & $70 \%$ & $54 \%$ & $78 \%$ \\
\hline $\begin{array}{l}\text { Maximum } \\
\text { value }\end{array}$ & 4,986 & 5,834 & 5,773 & 6048 & $\begin{array}{r}\text { Not } \\
\text { applicable }\end{array}$ & $\begin{array}{r}\text { Not } \\
\text { applicable }\end{array}$ \\
\hline $\begin{array}{l}\text { Date of } \\
\text { maximum } \\
\text { value }\end{array}$ & March 31 & April 5 & March 28 & April 11 & $\begin{array}{r}\text { Not } \\
\text { applicable }\end{array}$ & $\begin{array}{r}\text { Not } \\
\text { applicable }\end{array}$ \\
\hline \multicolumn{7}{|l|}{$\begin{array}{l}\text { Average product } \\
\text { of the infected, } \\
\text { AY, 5-day EMA }\end{array}$} \\
\hline Mean & 1,227 & 1,597 & 2,001 & 1,902 & 11,794 & 182 \\
\hline $\begin{array}{l}\text { Standard } \\
\text { deviation }\end{array}$ & 647 & 813 & 914 & 1,138 & 7,484 & 134 \\
\hline $\begin{array}{l}\text { Coefficient of } \\
\text { variation }\end{array}$ & $53 \%$ & $51 \%$ & $46 \%$ & $60 \%$ & $63 \%$ & $74 \%$ \\
\hline $\begin{array}{l}\text { Maximum } \\
\text { value }\end{array}$ & 1,917 & 2,481 & 2,923 & 2,997 & $\begin{array}{r}\text { Not } \\
\text { applicable }\end{array}$ & $\begin{array}{r}\text { Not } \\
\text { applicable }\end{array}$ \\
\hline $\begin{array}{l}\text { Date of } \\
\text { maximum } \\
\text { value }\end{array}$ & April 22-24 & April 20 & April 22-24 & Mey 18-19 & $\begin{array}{r}\text { Not } \\
\text { applicable }\end{array}$ & $\begin{array}{r}\text { Not } \\
\text { applicable }\end{array}$ \\
\hline
\end{tabular}

421 
431

\begin{tabular}{|c|c|c|c|c|c|c|}
\hline & France & Germany & Italy & The UK & The US & Indonesia \\
\hline \multicolumn{7}{|l|}{$\begin{array}{l}\text { Are } \\
\text { elasticity of } \\
\text { production, } \\
\text { 5-day EMA }\end{array}$} \\
\hline Mean & 1.83 & 1.67 & 1.45 & 2.20 & 2.91 & 2.83 \\
\hline $\begin{array}{l}\text { Standard } \\
\text { deviation }\end{array}$ & 1.80 & 1.76 & 1.44 & 1.62 & 2.10 & 0.72 \\
\hline $\begin{array}{l}\text { Coefficient } \\
\text { of } \\
\text { variation }\end{array}$ & $99 \%$ & $106 \%$ & $99 \%$ & $74 \%$ & $72 \%$ & $25 \%$ \\
\hline $\begin{array}{l}\text { Maximum } \\
\text { value }\end{array}$ & 6.08 & 5.92 & 4.32 & 5.97 & 9.07 & 5.82 \\
\hline $\begin{array}{l}\text { Minimum } \\
\text { value } * \text { ) }\end{array}$ & 0.17 & 0.17 & 0.08 & 0.34 & $\begin{array}{r}0.96 \\
\text { (outlier) }\end{array}$ & 1.84 \\
\hline \multicolumn{7}{|l|}{$\begin{array}{l}\text { Point } \\
\text { elasticity of } \\
\text { production, } \\
\text { 5-day EMA }\end{array}$} \\
\hline Mean & 1.62 & 1.48 & 1.30 & 1.99 & 2.61 & 2.60 \\
\hline $\begin{array}{l}\text { Standard } \\
\text { deviation }\end{array}$ & 1.55 & 1.52 & 1.23 & 1.42 & 1.76 & 0.56 \\
\hline $\begin{array}{l}\text { Coefficient } \\
\text { of } \\
\text { variation }\end{array}$ & $96 \%$ & $103 \%$ & $95 \%$ & $71 \%$ & $68 \%$ & $22 \%$ \\
\hline $\begin{array}{l}\text { Maximum } \\
\text { value }\end{array}$ & 4.91 & 5.14 & 3.82 & 5.27 & 7.62 & 4.10 \\
\hline $\begin{array}{l}\text { Minimum } \\
\text { value *) }\end{array}$ & 0.16 & 0.16 & 0.08 & 0.34 & $\begin{array}{r}0.94 \\
\text { (outlier) }\end{array}$ & 1.78 \\
\hline
\end{tabular}

432 Note: *) It excludes minimum values in the beginning of transmission.

433

434

435 Table 3. Probability of a policy target

436

\begin{tabular}{|c|c|c|c|c|c|c|}
\hline & France & Germany & Italy & The UK & The US & Indonesia \\
\hline $\begin{array}{l}\text { Policy (daily- } \\
\text { cases) target, I* }\end{array}$ & 500 & 500 & 500 & 1100 & $\begin{array}{l}\text { This analysis } \\
\text { is not } \\
\text { applicable for } \\
\text { the US }\end{array}$ & $\begin{array}{l}\text { This analysis } \\
\text { is not } \\
\text { applicable } \\
\text { for Indonesia }\end{array}$ \\
\hline $\begin{array}{l}\text { Probability of I } \\
(\mathrm{t}+1) \leq \mathrm{I}^{*} \text {, if: }\end{array}$ & & & & & & \\
\hline$\varepsilon \mathrm{t}>1$ & 0.00 & 0.00 & 0.00 & 0.00 & & \\
\hline $0 \leq \varepsilon \mathrm{t} \leq 1$ & 0.47 & 0.37 & 0.50 & 0.17 & & \\
\hline $0 \leq \varepsilon \mathrm{t} \leq 0.5$ & 0.63 & 0.46 & 0.63 & 0.41 & & \\
\hline $\begin{array}{l}0 \leq \varepsilon \mathrm{t} \leq 0.2 \\
(0 \leq \varepsilon \mathrm{t} \leq 0.4 \text { for } \\
\text { the UK) }\end{array}$ & 0.71 & 1.00 & 1.00 & 0.75 & & \\
\hline $\begin{array}{l}\text { Probability of I } \\
(\mathrm{t}+1) \leq \mathrm{I}^{*} \text { and } \\
\mathrm{I}(\mathrm{t}+1)<\mathrm{I}(\mathrm{t}) \text { if: }\end{array}$ & & & & & & \\
\hline$\varepsilon t>1$ & 0.00 & 0.00 & 0.00 & 0.00 & & \\
\hline $0 \leq \varepsilon t \leq 1$ & 0.29 & 0.26 & 0.35 & 0.15 & & \\
\hline $0 \leq \varepsilon \mathrm{t} \leq 0.5$ & 0.38 & 0.32 & 0.44 & 0.35 & & \\
\hline $\begin{array}{l}0 \leq \varepsilon \mathrm{t} \leq 0.2 \\
(0 \leq \varepsilon \mathrm{t} \leq 0.4 \text { for } \\
\text { the UK) }\end{array}$ & 0.29 & 0.33 & 0.67 & 0.50 & & \\
\hline
\end{tabular}


Figure 1: The relationship between $Y(t), M Y=I(t)$, and AY

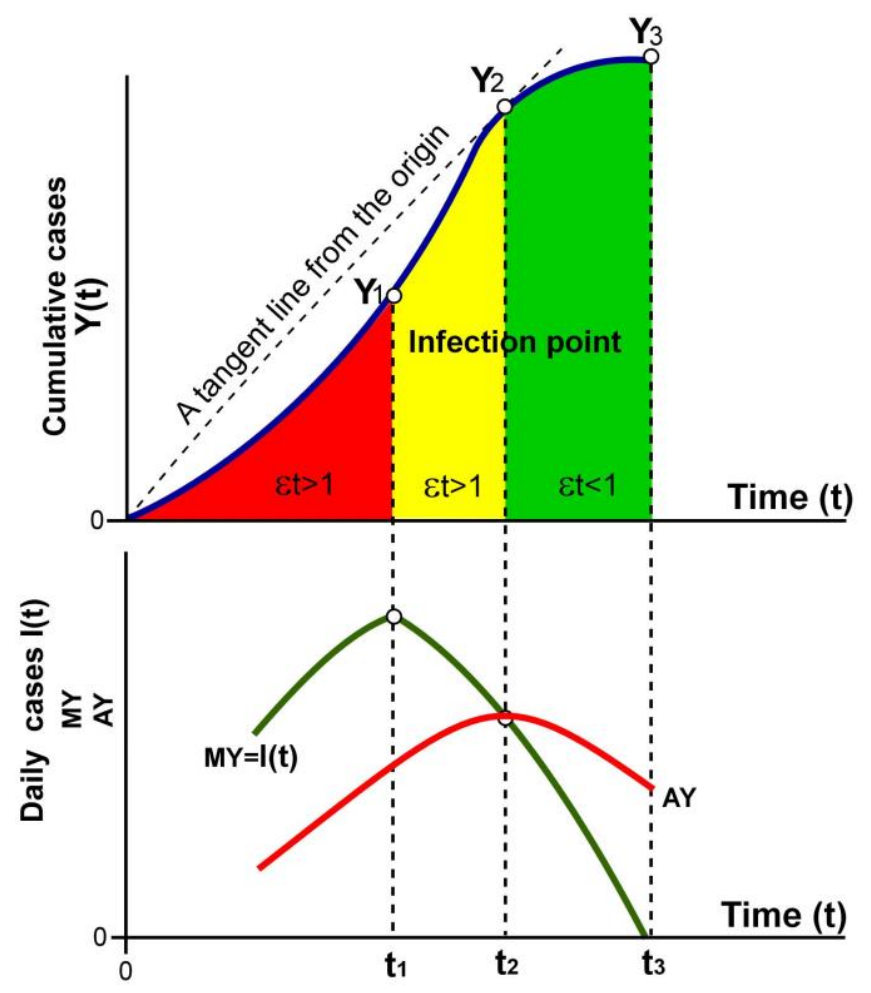


Figure 2: Cumulative number of cases, daily-cases, and average product of the infected
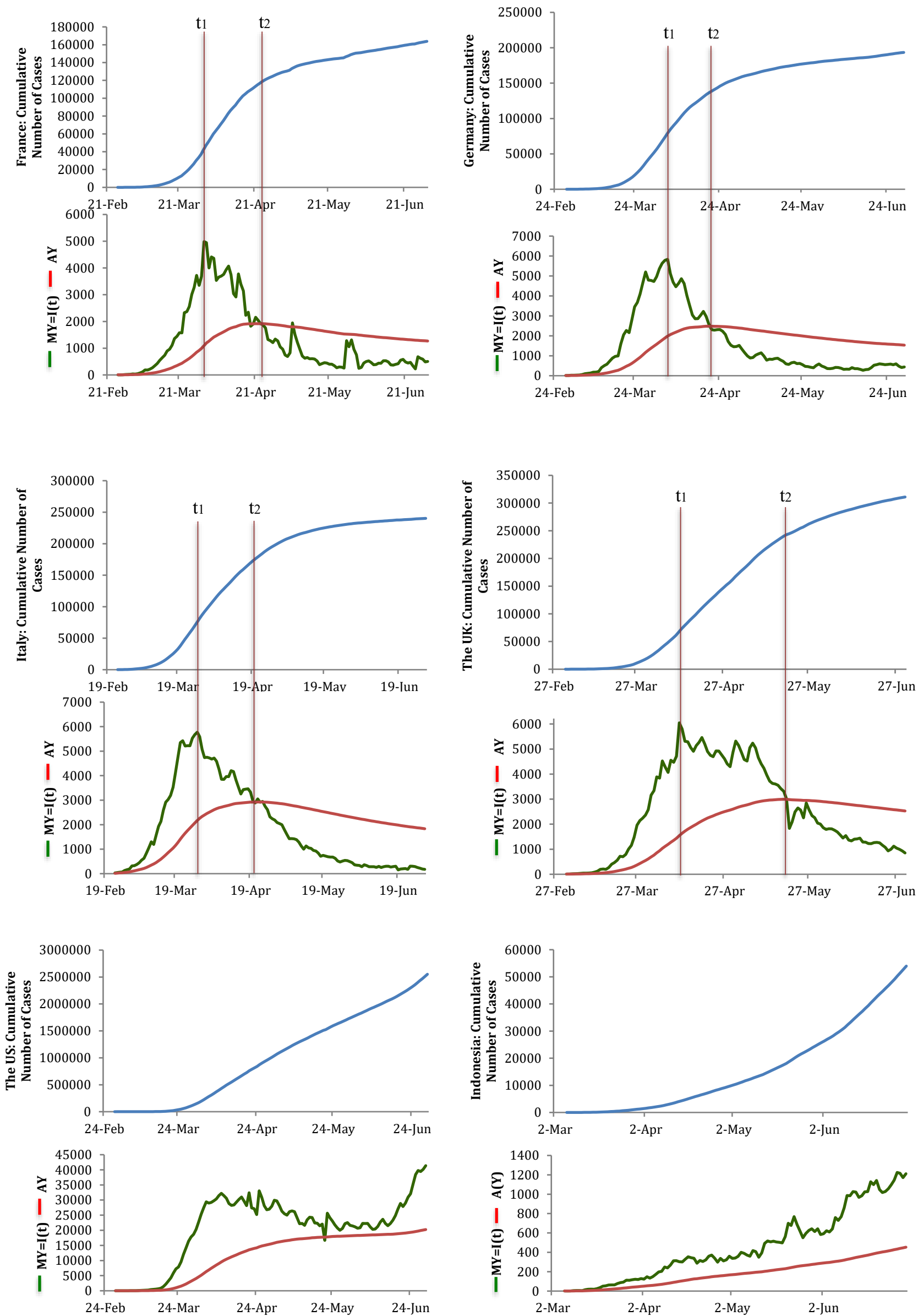


\section{$438 \quad$ Additional files}

439

440 File name: Additional file 1; Format: .docx; Title: Cumulative number of COVID-19 cases as a short-

441 run health production function; Description of data: a formal mathematical presentation of the method 442 used in this study.

443

444 File name: Additional file 2; Format: docx; Title: Figures; Description of data: $Y(t), M Y=I(t)$ and $A Y$ 445 curves from the original data.

446

447 File names: Additional_file_3 to 8_country name. Format: .xlsx; Title: Country name_COVID-19; 448 Description of data: All data collected and processed in this study, including the calculation formula 449 of each cell. 
Figures

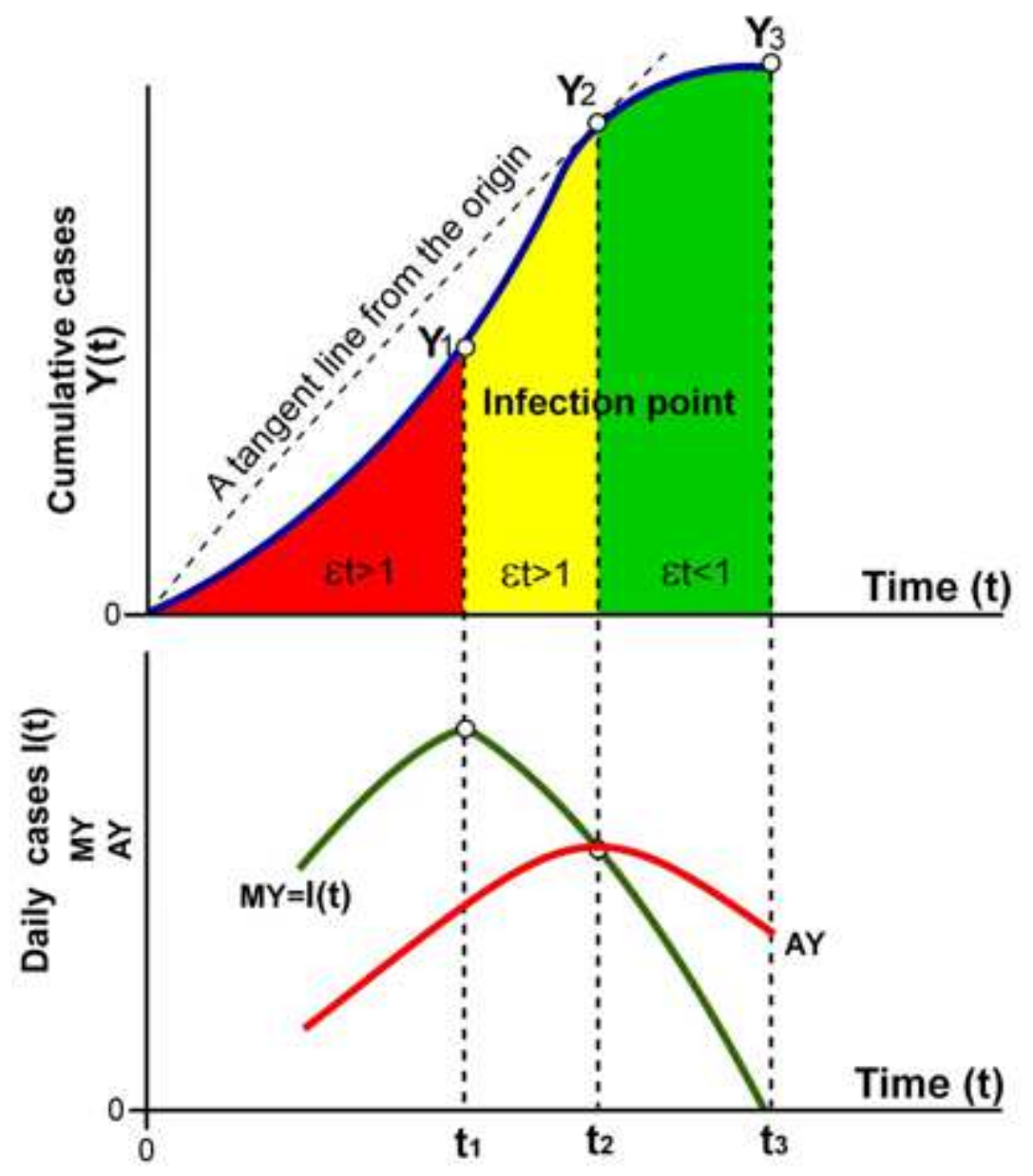

Figure 1

The relationship between $Y(t), M Y=I(t)$, and $A Y$ 

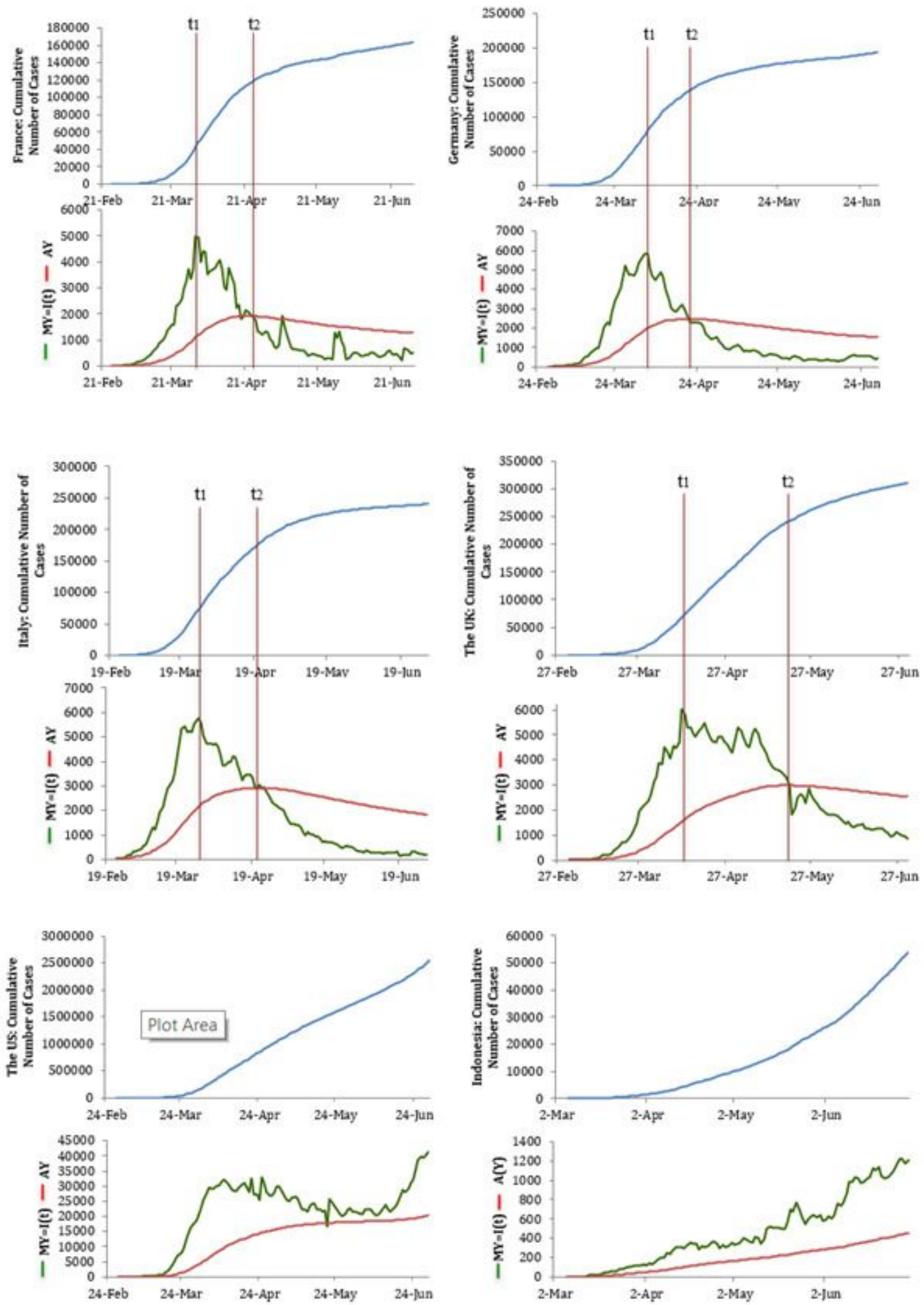

Figure 2

Cumulative number of cases, daily-cases, and average product of the infected

\section{Supplementary Files}

This is a list of supplementary files associated with this preprint. Click to download. 
- Additionalfile1.docx

- Additionalfile1.docx

- Additionalfile3France.xlsx

- Additionalfile3France.xIsx

- Additionalfile3France.xlsx

- Additionalfile3France.xlsx

- Additionalfile3France.xIsx

- supplement8.docx

- Additionalfile3France.xlsx

- supplement10.xlsx

- supplement11.xlsx

- supplement12.xlsx

- supplement13.xlsx

- supplement14.xlsx

- AdditionalFiles.docx 